Case Report

\title{
Prevention of Recurrent Urinary Tract Infections in Postmenopausal Women
}

\section{Pencegahan Infeksi Saluran Kemih Berulang pada Perempuan Pascamenopause}

\author{
Darrell Fernando, Budi I Santoso \\ Department Of Obstetrics and Gynecology \\ Faculty of Medicine University of Indonesia/ \\ Dr. Cipto Mangunkusumo General Hospital \\ Jakarta
}

\begin{abstract}
Objective: To determine the most effective and applicable methods to reduce recurrence of urinary tract infections in postmenopausal women.

Method: A search was conducted on Pubmed, NEJM, BMJ, and Google. After screening and selection, six articles were considered useful; comprising of two original research articles, one systematic review, and three society guidelines.

Result: Society guidelines recommended continuous antimicrobial prophylaxis, with postcoital antimicrobial prophylaxis as an alternative. The first research article found similar results in continous antimicrobial prophylaxis group and intermittent antimicrobial prophylaxis group. The second research article found no significant difference in cranberry and trimethoprim group. The systematic review revealed vaginal estrogens are effective in preventing recurrent UTI, but the type of estrogen is less clear. Oral estrogens are not effective.
\end{abstract}

Conclusion: Prevention of recurrent urinary tract infections in postmenopausal women include risk factor identification, non-antimicrobial prophylaxis with cranberry and vaginal estrogen preparations, and antimicrobial prophylaxis (continuous or intermittent).

[Indones J Obstet Gynecol 2014; 2-1: 55-60]

Keywords: postmenopausal, prevention, recurrent urinary tract infection.

\begin{abstract}
Abstrak
Tujuan: Mengetahui metode yang paling efektif dan yang paling dapat diterapkan untuk mencegah berulangnya infeksi saluran kemih pada perempuan pascamenopause.

Metode: Pencarian literatur dilakukan di Pubmed, NEJM, BMJ, dan Google. Setelah dilakukan skrining dan pemilihan literatur, didapatkan enam literatur yang sesuai dengan pertanyaan klinis. Literatur tersebut terdiri dari dua artikel penelitian, satu telaah sistematis, dan tiga panduan organisasi.

Hasil: Pada panduan organisasi, dianjurkan untuk menggunakan antibiotik profilaksis kontinu sebagai pencegahan ISK berulang, dengan antibiotik pascakoitus sebagai alternatif. Pada artikel penelitian pertama tidak ditemukan perbedaan pada kelompok antibiotik pro-filaksis dan intermiten. Pada artikel penelitian kedua tidak ditemukan perbedaan pada kelompok cranberry dan trimetoprim. Pada telaah sistematis disimpulkan bahwa sediaan estrogen vagina efektif untuk mencegah berulangnya ISK. Estrogen oral tidak efektif untuk mencegah berulangnya ISK.
\end{abstract}

Kesimpulan: Pencegahan ISK berulang pada perempuan pascamenopause mencakup identifikasi faktor risiko, profilaksis non-antimikroba dengan cranberry dan preparat estrogen vagina, dan profilaksis antimikroba, baik kontinu maupun intermiten.

[Maj Obstet Ginekol Indones 2014; 2-1: 55-60]

Kata kunci: infeksi saluran kemih berulang, pascamenopause, pencegahan.

Correspondence: Darrell Fernando. Jln. Gunung Atlantik 79, Taman Diponegoro, Lippo Karawaci, Tangerang 15811.

Mobile: 081389900846, Telephone:021-3928741 Email:dr.darrellfernando@gmail.com

\section{CLINICAL SCENARIO}

A 68 year old woman presented to the clinic with dysuria and urinary frequency. Subsequent physical examinations and laboratory tests revealed a positive urinary tract infection. She has been treated for urinary tract infections 3 times in the past 8 months. The patient asked how to prevent recurrent episodes of urinary tract infections as it significantly decreases her quality of life.

\section{INTRODUCTION}

Urinary tract infections (UTI) are commonly found in daily practice. International Urogynecological Association/International Continence Society (2010) defined recurrent urinary tract infections as at least three symptomatic and medically diagnosed UTI in the previous 12 months. The previous UTIs should have resolved prior to a further UTI being diagnosed. ${ }^{1}$ 
Escherichia coli is the main causative pathogen involved in recurrent UTIs, accounting for $80 \%$ of infections. ${ }^{2}$ Even though the pathogen is the same, risk factors for recurrent UTIs differ in premenopausal and postmenopausal women. In premenopausal women, behaviour risk factors such as frequency of intercourse, use of spermicide, and new sexual partners may increase colonization of E. coli in the vagina and periurethral region.,4 In postmenopausal women, estrogen loss results in thinning of the vaginal epithelium and decreased amounts of glycogen. As a result, amount of lactobacilli decreases and there is an increased risk of colonization with uropathogens. Moreover, associated pathologies such as incontinence, pelvic floor prolapse, and urinary retention increase the risk for recurrent UTI. ${ }^{5}$

Various studies have reported the use of antimicrobials and non-antimicrobials such as estrogen and cranberry for preventing recurrence of UTI. In this EBCR we tried to appraise novel studies and guidelines in order to obtain information that may be applied to our case.

\section{CLINICAL QUESTION}

The question in the scenario is "In post-menopausal women, what are the effective and applicable methods to reduce the recurrence of urinary tract infections?"

\section{METHODS}

\section{Search Strategy}

The search was conducted on Pubmed, NEJM, and BMJ on February 8, 2013, using the search tool containing the keywords "recurrent urinary tract infection", "treatment", "prophylaxis", "elderly women", and "postmenopausal". Another search was performed on Google to find organizational or society guidelines on recurrent urinary tract infections. Search results were filtered by the engine according to the following criteria: articles published in the past 5 years, female, human species, and English language. Search strategy, results, and the inclusion and exclusion criteria are shown in a flowchart (Figure 1).

\section{Selection}

The titles of the filtered results from Pubmed, NEJM, and BMJ were screened using the inclusion criteria. There were no same articles from all three engines. A second screen was conducted by reading the abstracts, and finally 3 articles were useful. Three society guidelines were found on Google, from Society of Obstetricians and Gynaecologists of Canada (SOGC), American College of Obstetricians and Gynecologists (ACOG), and European Association of Urology (EAU). In this report a total of 6 articles were appraised.

\section{Critical Appraisal}

Two articles were original researches, one article was a systematic review, and three articles were society guidelines. All were appraised according to the corresponding type of article, comprising of its validity, importancy, and applicability to the patient (Table 1-2). The checklists used were obtained from www.bmj.com.

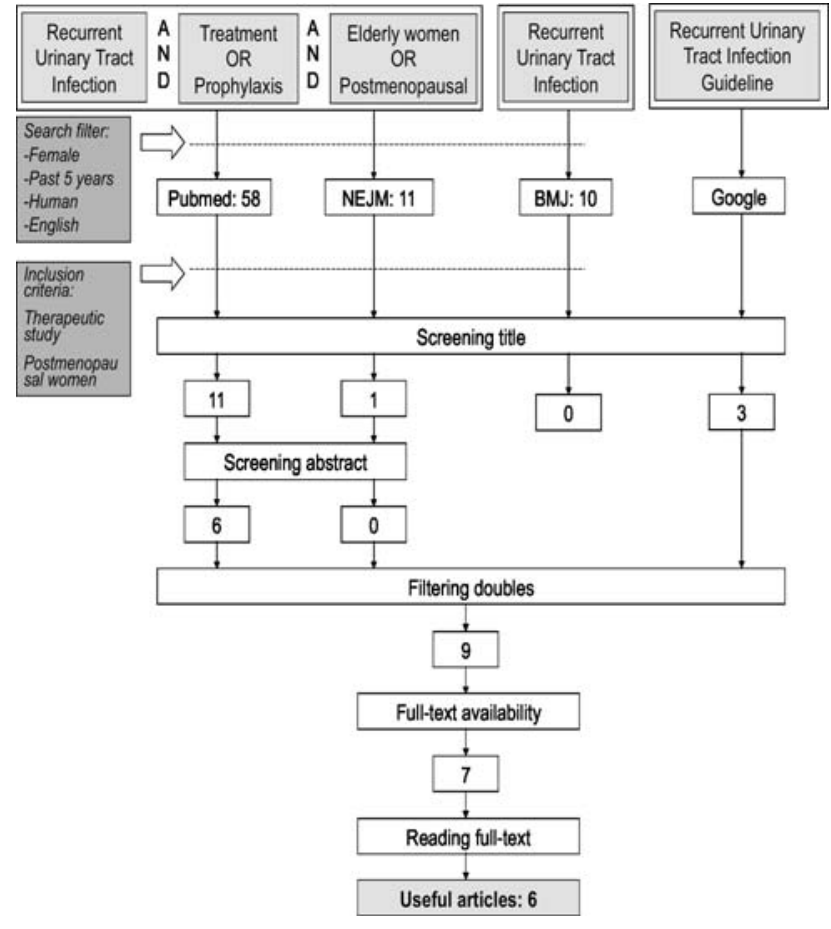

Figure 1. Flowchart of Search Strategy. 
Table 1. Critical Appraisal of Original Research Articles and Systematic Review.

\begin{tabular}{lcc}
\hline \hline \multicolumn{1}{c}{ Study/Criteria } & \multicolumn{1}{c}{$\begin{array}{c}\text { Zhong et al6 } \\
\text { Experiment: intermittent prophylactic antibiotic } \\
\text { Control: continuous prophylactic antibiotic }\end{array}$} & $\begin{array}{c}\text { McMurdo et al7 } \\
\text { Experiment: cranberry } \\
\text { Control: trimethoprim }\end{array}$ \\
\hline $\begin{array}{l}\text { Validity } \\
\text { - Randomisation }\end{array}$ & Yes & Yes \\
- Intention to treat analysis & No & Yes \\
- Blinding & No & Double-blinding \\
- Equal treatment besides experiment & Yes & Yes \\
- Similarity of groups & Yes & Yes \\
Importance & & $20.6 \%$ \\
- Control event rate (CER) & $29.8 \%$ & $36.2 \%$ \\
- Experimental event rate (EER) & $37.3 \%$ & $-15.6 \%$ (increased risk) \\
- Relative risk reduction (RRR) & $-7.5 \%$ (increased risk) & $-75.7 \%$ (increased risk) \\
- Absolute risk reduction (AAR) & $-25.2 \%$ (increased risk) & -2 (harm) \\
- Number needed to treat (NNT) & -4 (harm) & \\
Applicability & & Yes \\
- Can the results help the patient? & Yes & Yes \\
- Potential benefit of therapy & Yes & - \\
- Patient satisfaction & - & \\
\hline
\end{tabular}

Table 2. Critical Appraisal of Systematic Reviews.

\section{Study/Criteria}

\section{Validity}

- Review of randomised trials

- Explanation about finding and including all relevant trials

- Assessing validity of individual trials

- Consistency of results

- Individual or aggregate data

\section{Importancy}

- Relative risk (95\%CI)

\section{Applicability}

- Can the results help the patient?

- Potential benefit of therapy

- Patient satisfaction
Perrotta et al ${ }^{8}$

Review of benefit of estrogen

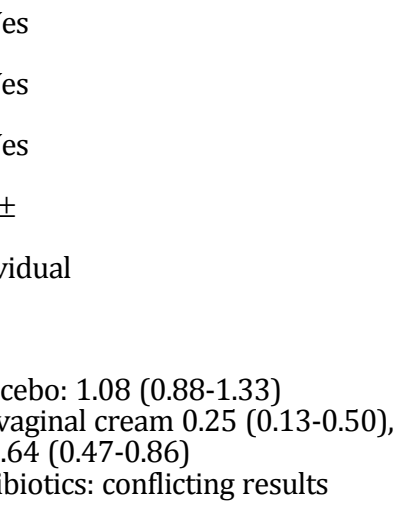

Vagina estrogens vs placebo: vaginal cream 0.25 (0.13-0.50),

Vaginal ring 0.64 (0.47-0.86)

Vaginal estrogens vs antibiotics: conflicting results 


\section{RESULTS}

Zhong et al conducted a randomised controlled study on 83 postmenopausal women, comparing the effectiveness and safety of patient-initiated single-dose versus continuous low-dose antibiotics. The incidence of urinary tract infections were significantly reduced in both groups, from 5.1 to 1.9 episodes/patient per year $(\mathrm{p}<0.001)$ in the intermittent group, and from 4.7 to 1.4 episodes/patient per year $(\mathrm{p}<0.001)$ in the continuous group. The difference between both groups were not statistically significant. The continuous group had significantly less patients experiencing 0 or 1 episode/ year than the intermittent group (59.4\% vs $35.5 \%$, $\mathrm{p}<0.05$ ), but it was also associated with significantly higher adverse effects $(92.5 \%$ vs $63.6 \%, \mathrm{p}<$ $0.05)^{6}$

McMurdo et al conducted a double-blind, randomised controlled trial with 137 samples. Occurences of UTI in cranberry group and trimethophrim group was $36.2 \%$ and $20.6 \%$, respectively. The differences in this proportion was not statistically significant ( $\mathrm{p}$ 0.084). Withdrawal rate was $9 \%$ from the cranberry group and $16 \%$ from the trimethoprim group $(\mathrm{p}=0.205){ }^{7}$

Perrotta et al reviewed the effectiveness of estrogens for preventing recurrent UTI in postmenopausal women. Nine articles were reviewed, with three main interventions being conducted: oral estrogens vs placebo, vaginal estrogens vs placebo, and vaginal estrogens vs antibiotics. There was no significant difference in the number of women with UTI in the oral estrogen vs placebo group (RR 1.08, 95\%CI 0.88-1.33). In the vaginal estrogen group, both intravaginal estrogen cream (RR $0.25,95 \% \mathrm{CI} 0.13-0.50$ ) and silicone vaginal ring (RR 0.64, 95\%CI 0.47-0.86) significantly reduced the recurrence of UTI. Results in the vaginal estrogen vs antibiotics group were conflicting, one study found less UTI in the antibiotic group (RR 1.30, 95\% CI 1.01-1.68) while the other study found less UTI in the estrogen group (RR 0.09, 95\% CI 0.02-0.36). ${ }^{8}$

SOGC recommended continuous daily antibiotic prophylaxis to prevent recurrent UTI. Post-coital prophylaxis may be used as an alternative in women with recurrent UTI associated with sexual intercourse to minimize cost and side effects. Antibiotics that can be used as prophylaxis are listed in Table 5. Acute-self treatment should only be restricted to compliant and motivated patients. Vaginal estrogens and cranberry products are also effective. ${ }^{9}$

Table 3. Antimicrobial Prophylaxis for Women with Recurrent Urinary Tract Infections.9

\begin{tabular}{ll}
\hline \hline Oral regimens & \multicolumn{1}{c}{ Dose } \\
\hline Continuous prophylaxis & \\
- Cotrimoxazole & $1 \times 240 \mathrm{mg}$ (daily) \\
- Nitrofurantoin & $1 \times 50-100 \mathrm{mg}$ (daily) \\
- Cephalexin & $1 \times 125-250 \mathrm{mg}$ (daily) \\
- Ciprofloxacin & $1 \times 125 \mathrm{mg}$ (daily) \\
- Norfloxacin & $1 \times 200 \mathrm{mg}$ (daily) \\
Post-coital prophylaxis & $240-480 \mathrm{mg}$ single dose \\
- Cotrimoxazole & $100 \mathrm{mg}$ single dose \\
- Nitrofurantoin & $125-250 \mathrm{mg}$ single dose \\
- Cephalexin & $125 \mathrm{mg}$ single dose \\
- Ciprofloxacin & $100 \mathrm{mg}$ single dose \\
- Ofloxacin & $200 \mathrm{mg}$ single dose \\
\hline
\end{tabular}

EAU recommended non-antimicrobial prophylaxis such as cranberry as a first line of prevention. If unsuccessful, continuous or postcoital antimicrobial prophylaxis should be considered. ${ }^{10}$

ACOG recommended to first search for known risk factors associated with recurrence, such as frequent intercourse, long-term spermicide use, diaphragm use, new sexual partner, young age at first UTI, and maternal history of UTI. Similar to other guidelines, prophylaxis can be continuous or postcoital. $^{11}$

\section{COMMENTARY}

In general, all appraised articles showed similar methods or recommendations to prevent recurrent UTI.

All three society guidelines satisfied the validity, 
usefulness, and applicability criteria. Recommendations are applicable in daily practice, and all three guidelines support each other. Continuous or postcoital antibiotics to prevent recurrent UTI was recommended in all three guidelines. ${ }^{9-11}$

Zhong et al conducted a very interesting research concerning antimicrobial prophylaxis, comparing continuous or intermittent antibiotic prophylaxis as recommended by all three society guidelines. Predisposing factors used to determine when to begin prophylactic single-dose antibiotic are: working or walking $>2$ hours, travelling, emiction holdback, sexual intercourse, diarrhea, and constipation. The authors concluded that patientinitiated intermittent antibiotic use against specific predisposing factors showed similar effectiveness with continuous antibiotic use, but with less gastrointestinal adverse events. ${ }^{6}$ Nevertheless, results proved unsignificant statistically may be significant clinically, so we must consider the risk and benefits when choosing mode of antimicrobial prophylaxis. Continuous prophylaxis may be more effective for preventing recurrence of UTI than intermittent prophylaxis, but is associated with more side effects. The weakness in this study is the lack intention-to-treat analysis, as it may affect the results.

McMurdo et al compared the effectiveness of cranberry to trimethoprim. It is a well-conducted study with double-blinding and intention-to-treat analysis. Results could have been more conclusive and applicable if they included another group treated with vaginal estrogens. Cranberry and trimethoprim had no significant differences in terms of reducing UTI and adverse effects. ${ }^{7}$

Perrotta et al conducted a systematic review to evaluate the role of estrogens in preventing recurrent UTIs. This review is valid and important, but may not be applied directly as the researches reviewed are few small studies. They concluded that vaginal estrogens are effective, but the type of estrogen to use is less clear. Vaginal creams are cheaper but may be hard to apply for some women as it has to be applied every day. Vaginal rings are expensive and requires a trained doctor to place correctly. Oral estrogens are not effective to prevent recurrent UTIs. ${ }^{8}$

\section{CONCLUSION AND RECOMMENDATIONS}

Prevention of recurrent urinary tract infections in postmenopausal women include risk factor identification, non-antimicrobial prophylaxis, and antimicrobial prophylaxis. Consumption of cranberry and usage of vaginal estrogens are effective nonantimicrobial measures. Antimicrobial prophylaxis are divided into continuous single dose daily prophylaxis and intermittent self-initiated prophylaxis. Choice of prophylaxis method depends on the compliance of the patient, as intermittent self-initiated prophylaxis require identification and awareness on when to consume the drug.

In Indonesia, there are limitations in the non-antimicrobial prophylaxis group. Vaginal estrogens are expensive and cranberry are hard to obtain. Therefore, the mode of prevention is suited to the preference of the patient and availability of drugs in that area.

\section{REFERENCES}

1. Haylen BT, de Ridder D, Freeman RM, Swift SE, Berghmans B, Lee J. An International Urogynecological Association (IUGA)/International Continence Society (ICS) joint report on the terminology for female pelvic floor dysfunction. Neurourol Urodyn. 2010; 29(1): 4-20.

2. Echols RM, Tosiello RL, Haverstock DC, Tice AD. Demographic, clinical, and treatment parameters influencing the outcome of acute cystitis. Clin Infect Dis. 1999 Jul; 29(1): 113-9.

3. Scholes D, Hooton TM, Roberts PL, Stapleton AE, Gupta K, Stamm WE. Risk factors for recurrent urinary tract infection in young women. J Infect Dis. 2000 Oct; 182(4): 1177-82.

4. Foxman B, Gillespie B, Koopman J, Zhang L, Palin K, Tallman $P$. Risk factors for second urinary tract infection among college women. Am J Epidemiol. 2000; 15: 151 (12): 1194-205.

5. Gupta K, Stamm WE. Pathogenesis and management of recurrent urinary tract infections in women. World J Urol. 1999; 17(6): 415-20.

6. Zhong YH, Fang Y, Zhou JZ, Tang Y, Gong SM, Ding XQ. Effectiveness and safety of patient initiated single-dose versus continuous low-dose antibiotic prophylaxis for recurrent urinary tract infections in postmenopausal women: a randomized controlled study. J Int Med Res. 2011; 39(6): 233543.

7. McMurdo ME, Argo I, Phillips G, Daly F, Davey P. Cranberry or trimethoprim for the prevention of recurrent urinary tract infections? A randomized controlled trial in older women. J Antimicrob Chemother. 2009; 63(2): 389-95.

8. Perrotta C, Aznar M, Mejia R, Albert X, Ng CW. Oestrogens for preventing recurrent urinary tract infection in postmenopausal women. Cochrane Database Syst Rev. 2008(2): CD005131. 
9. Epp A, Larochelle A, Lovatsis D, Walter JE, Easton W, Farrell SA. Recurrent urinary tract infection. J Obstet Gynaecol Can. 2010; 32(11): 1082-101.

10. Grabe M, Bjerklund-Johansen TE, Botto H, Wullt B, Çek M, Naber KG. Guidelines on urological infections. EAU Guidelines, edition presented at the $25^{\text {th }}$ EAU Annual Congress. Barcelona 2011.
11. American College of O, Gynecologists. ACOG Practice Bulletin No. 91: Treatment of urinary tract infections in nonpregnant women. Obstet Gynecol. 2008; 111(3): 785-94. 